\title{
Induced Resistance for Plant Disease Control: Maximizing the Efficacy of Resistance Elicitors
}

\author{
Dale Walters, David Walsh, Adrian Newton, and Gary Lyon
}

First and second authors: Crop and Soil Research Group, Scottish Agricultural College, King's Buildings, West Mains Road, Edinburgh EH9

3JG, UK; and third and fourth authors: Scottish Crop Research Institute, Invergowrie, Dundee, DD2 5DA, UK.

Accepted for publication 15 July 2005.

\begin{abstract}
Walters, D., Walsh, D., Newton, A., and Lyon, G. 2005. Induced resistance for plant disease control: Maximizing the efficacy of resistance elicitors. Phytopathology 95:1368-1373.

Plants can be induced to develop enhanced resistance to pathogen infection by treatment with a variety of abiotic and biotic inducers. Biotic inducers include infection by necrotizing pathogens and plant-growthpromoting rhizobacteria, and treatment with nonpathogens or cell wall fragments. Abiotic inducers include chemicals which act at various points in the signaling pathways involved in disease resistance, as well as water stress, heat shock, and $\mathrm{pH}$ stress. Resistance induced by these agents (resistance elicitors) is broad spectrum and long lasting, but rarely pro-

viding between 20 and $85 \%$ disease control. There also are many reports of resistance elicitors providing no significant disease control. In the field, expression of induced resistance is likely to be influenced by the environment, genotype, and crop nutrition. Unfortunately, little information is available on the influence of these factors on expression of induced resistance. In order to maximize the efficacy of resistance elicitors, a greater understanding of these interactions is required. It also will be important to determine how induced resistance can best fit into disease control strategies because they are not, and should not be, deployed simply as "safe fungicides". This, in turn, will require information on the interaction of resistance elicitors with crop management practices such as appropriate-dose fungicide use.
\end{abstract} vides complete control of infection, with many resistance elicitors pro-
It is now well documented that treatment of plants with various agents (e.g., virulent or avirulent pathogens, nonpathogens, cell wall fragments, plant extracts, and synthetic chemicals) can lead to the induction of resistance to subsequent pathogen attack, both locally and systemically (74). This induced resistance rarely leads to complete control of pathogens following subsequent inoculation, but rather results in, for example, a reduction in lesion numbers and size (34). Most notably, the expression of this induced resistance does not require the presence of major pathogenspecific resistance genes, although the defense mechanisms activated are those used in other forms of plant resistance to pathogens (21). Following application of an inducing treatment to a plant, defense mechanisms may be triggered directly or they may be triggered only once pathogen challenge has occurred (72). The defense responses activated include an oxidative burst, which can lead to cell death (21), thereby trapping the pathogen in dead cells; changes in cell wall composition that can inhibit pathogen penetration; and synthesis of antimicrobial compounds such as phytoalexins (20). Induction of systemic resistance can lead to the direct activation of defense-related genes, but also can lead to the priming of cells, resulting in stronger elicitation of those defenses or, indeed, other defenses following pathogen attack (11).

Induced resistance can be split broadly into systemic acquired resistance (SAR) and induced systemic resistance (ISR). SAR develops locally or systemically in response to, for example, pathogen infection or treatment with certain chemicals (e.g., 2,6-dichloroisonicotinic acid [INA]) is effective against a wide range of pathogens and is mediated by a salicylic acid [SA]-dependent process (74). In contrast, ISR develops as a result of colonization

Corresponding author: D. Walters: E-mail address: dale.walters@sac.ac.uk

DOI: 10.1094/PHYTO-95-1368

(c) 2005 The American Phytopathological Society of plant roots by plant-growth-promoting rhizobacteria (PGPR) and is mediated by a jasmonate- or ethylene-sensitive pathway (50).

The prospect of broad-spectrum disease control using the plant's own resistance mechanisms has led to increasing interest in the development of agents which can mimic natural inducers of resistance (74). Research has focused on the elicitor molecules released during the early stages of the plant-pathogen interaction, and on the signaling pathways used to trigger defenses locally and systemically. The elicitors examined include carbohydrate polymers, lipids, and glycoproteins, and are either secreted by microorganisms or derived from the cell walls of fungi, bacteria, or plants (74) (e.g., elicitors derived from yeast cell walls) (52). Compounds which might mimic the action of SA include INA and $S$-methylbenzo[1,2,3]thiadiazole-7-carbothiate (acibenzolar- $S$ methyl) (ASM). Neither INA nor ASM possess antimicrobial activity in vitro, and they activate the same genes as does biological or SA induction of resistance (33). Indeed, ASM is the first synthetic chemical developed and marketed as a SAR activator and is marketed in Europe as BION and as ACTIGARD in the United States (74).

\section{INDUCED RESISTANCE AND DISEASE CONTROL: EXAMPLES FROM CONTROLLED ENVIRONMENT AND FIELD STUDIES}

There is a growing body of information on the efficacy of induced resistance under field conditions (70). In their review of induced resistance in conventional agriculture, Vallad and Goodman (70) highlighted 32 examples where ASM was found to provide disease control. In 28 of these studies, reductions in disease severity provided by ASM ranged from 4 to $80 \%$, with only 3 studies reporting disease control in excess of $80 \%$ (70). ASM was marketed originally for the control of powdery mildew on wheat and barley in Europe (16) and, indeed, has been shown to reduce mildew infection on wheat by between 64 and $77 \%$ in 
field experiments $(65,66)$. However, some of the best levels of disease control were demonstrated on dicotyledenous crops. For example, on tobacco, ASM provided $99 \%$ control of Pseudomonas syringae pv. tabaci, $91 \%$ control of Cercospora nicotiana, and $89 \%$ control of Alternaria alternata $(10,49)$. They also highlighted 60 examples where PGPR were used to control crop diseases, with reductions in disease severity of less than $80 \%$ reported in 57 of the studies (70). Particularly high levels of disease control were achieved in cucumber, with Bacillus pumilis INR-7 and Serratia marcescens 90-166 providing 86 and $89 \%$ control, respectively, of Erwinia tracheiphila (78).

But what about the diverse range of other agents that have been shown to induce resistance? These include phosphates, amino acids, fatty acids, cell wall fragments, and avirulent pathogens (74) which characteristically are either far less toxic than fungicides or nontoxic because they do not act directly against pathogens but entirely through the plant's defense mechanisms.

Induced resistance using phosphate salts. Dibasic and tribasic phosphate salts were shown to induce systemic protection against anthracnose in cucumber caused by Colletotrichum lagenarium (17) and later work demonstrated the broad spectrum of disease control achieved in cucumber using phosphates (40). It was speculated that basic phosphates applied to plants could sequester apoplastic calcium, altering membrane integrity and influencing the activity of apoplastic enzymes such as polygalacturonases, thereby releasing elicitor-active oligogalacturonides from plant cell walls $(17,73)$. Indeed, subsequent work by Orober et al. (48) showed that phosphate-mediated resistance induction in cucumber was associated with localized cell death, preceded by a rapid generation of superoxide and hydrogen peroxide. These workers also detected local and systemic increases in levels of free and conjugated SA following phosphate application (48). Recent work on barley showed that application of phosphate to first leaves reduced powdery mildew infection by $89 \%$ in second leaves (39). Application of phosphate to first leaves led to significant increases in activities of phenylalanine ammonia-lyase, peroxidase, and lipoxygenase in second leaves, and activities of these enzymes were increased further following pathogen challenge (39). Phosphates also have been shown to provide disease control under field conditions. Thus, $\mathrm{K}_{2} \mathrm{HPO}_{4}$ applied to rice as a 50 -mM spray reduced neck blast caused by the fungus Pyricularia oryzae by between 29 and $42 \%$, with increases in grain yield of between 12 and $32 \%$ (36). Phosphate $\left(\mathrm{K}_{3} \mathrm{PO}_{4}, 25 \mathrm{mM}\right)$ applied to barley in a field trial reduced powdery mildew infection by up to $70 \%$ and gave an increase in grain yield of $12 \%$ compared with untreated controls (39). In cucumbers grown hydroponically, phosphate at $20 \mathrm{ppm}$ applied to the hydroponic solution reduced powdery mildew infection by between 80 and $92 \%$, with reductions of up to $91 \%$ in numbers of conidia produced on infected leaves (53).

Induced resistance using $\beta$-aminobutyric acid. The nonprotein amino acid $\beta$-aminobutyric acid (BABA) has been shown to induce broad-spectrum resistance in a range of crops (32). BABA applied to tobacco as a $1-\mathrm{mM}$ spray causes small necrotic lesions (8) and, when applied at $10 \mathrm{mM}$, led to the formation of reactive oxygen species, lipid peroxidation, induction of callose around lesions, and an increase in the SA content of leaves (61). Treatment with BABA has been reported to lead to induction of pathogenesis-related (PR) proteins. Treatment with BABA induced PR-1a, chitinase, and glucanase in tobacco, tomato, and pepper $(9,61)$, but not in Arabidopsis, cauliflower, or tobacco $(8,32,62)$. This suggests that induction of PR proteins may not be the only mode of action of BABA, which also leads to callose deposition, lignification, and hypersensitivity in some plants $(9,61)$. BABA has been shown to move systemically in tomato, tobacco, and grape plants (9), and this may explain the systemic protection against diseases observed in these and other plants $(9,61)$. In field trials with grapevines, BABA reduced infection by the downy mildew fungus Plasmopara viticola by $57 \%$ on cv. Chardonnay and by $98 \%$ on cv. Cabernet Sauvignon (54). Interestingly, mixtures of BABA and fungicides were even more effective in reducing infection in both cultivars.

Induced resistance using oligosaccharides. Oligosaccharides such as $N$-acetylchito-oligosaccharides and $\beta$-1,3-glucans are well known to act as elicitors of plant defenses. Chitosan is a deacetylated form of $\mathrm{N}$-acetylchito-oligosaccharides containing polyD-glucosamine and is a common polymer in shells of crustaceans, exoskeletons of insects, and cell walls of fungi (19). There are numerous reports of the protective effects of chitosan against pathogen infection in a range of crops. For example, chitosan seed treatment has been shown to protect tomato plants from crown rot and root rot (6) and to protect tomato seedlings against Fusarium oxysporum when applied as a foliar spray (7). A commercial formulation of chitosan developed by Glycogenesys Inc. (Boston), Elexa, contains $4 \%$ chitosan as its active ingredient and has been shown to protect a range of crops against important pathogens (1). In field trials with pearl millet, Elexa was shown to reduce downy mildew severity by $58 \%$ when used as a seed treatment, by $75 \%$ when used as a foliar spray, and by $77 \%$ when used as a combined seed treatment and foliar spray (59). Elicitors derived from the yeast Saccharomyces cerevisiae also have been shown to control plant diseases, providing up to $95 \%$ control of powdery mildew infection in barley in field trials $(51,52)$. In that work, elicitor applied with a reduced rate of fungicide gave better disease control than the elicitor used on its own.

Induced resistance using probenazole. The synthetic compound probenazole has been used to control rice blast caused by Magnaporthe grisea in Asia for more than 20 years and also protects rice from other diseases, including bacterial blight caused by Xanthomonas oryzae pv. oryzae (31). The probenazole-containing product Oryzemate provides long-lasting control of rice blast when applied to paddy fields or to seedling boxes. It is absorbed by roots and distributed throughout the plant, and the disease control it provides lasts for up to 70 days after application (31). Importantly, despite its extensive use since the 1970s, there have been no reports of resistance development in the blast fungus (31). Early studies showed that probenazole possessed only weak antimicrobial activity, leading workers to suggest that it activated defense responses in rice (75). Indeed, recent work has confirmed this and shown that probenazole and its active metabolite 1,2benzisothiazole-1,1-dioxide induce SAR by triggering signaling at a point upstream of SA accumulation (42).

\section{FACTORS INFLUENCING THE EXPRESSION OF INDUCED RESISTANCE}

From what we have considered so far, it is clear that, although there are cases where elicitors of induced resistance can provide very high levels of disease control $(>85 \%)$, there are many more examples of induced resistance providing lower levels of disease control (38). Indeed, there are also many reports of induced resistance not providing disease control. Thus, following a 2-year field trial with eight different cultivars of winter barley, Huth and Balke (29) concluded that ASM did not induce resistance to Barley yellow dwarf virus and, under controlled conditions, ASM did not induce resistance to Phytophthora brassicae in Arabidopsis or $P$. infestans in potato (60). More recently, in an evaluation of the effects of different agents on control of $X$. axonopodis $\mathrm{pv}$. citrumelo and $X$. axonopodis pv. citris on sweet oranges, ASM and the harpin protein (marketed as Messenger) failed to provide significant disease control (18). Because induced resistance is a plant response to attempted infection, it stands to reason that the expression of this response will be affected by a range of factors, including genotype and the environment. Therefore, how much do we know about the influence of these factors on the expression of induced resistance? 
Effects of genotype on the expression of induced resistance. In monocots, resistance activated by ASM typically is very long lasting, whereas the lasting effect is less pronounced in dicots (47). Comparatively little information exists on the influence of genotype on induced resistance. In some of the first work on this topic, Steiner et al. (67) reported that the reduction in powdery mildew on barley following treatment with culture filtrate of B. subtilis was cultivar specific and was most marked in partially resistant cultivars. In some later work, Martenelli et al. (37) studied resistance in barley to powdery mildew, induced by prior inoculation with an avirulent isolate of the powdery mildew fungus, Blumeria graminis f. sp. hordei. They used three sets of nearisogenic lines of barley, each of which included cultivars with four different race-specific resistance genes. Martenelli et al. (37) found that the extent of induced resistance, expressed as a reduction in the number of colonies formed, differed in lines carrying different race-specific resistance genes, being most effective in lines with the Mla7 gene and least effective in lines with the Mla13 gene. When induced resistance was measured at a later stage of infection, as a reduction in spore production, the effect was greatest in Mla 7 lines and was weakest in Mla6 and Mlh lines (37). A year later, Hijwegen and Verhaar (28) showed that resistance in cucumber to the powdery mildew fungus Sphaerotheca fuliginea, induced by treatment with INA, also was cultivar dependent, with the highest levels of induced resistance expressed in a partially resistant cultivar and much lower levels of resistance in susceptible cultivars. Different results were obtained by Dann et al. (12) working on soybean. They found that resistance to Sclerotinia sclerotiorum induced by treatment with INA or ASM was greatest in susceptible cultivars, thereby showing that induced resistance is not related to major gene resistance. Cultivardependent differences in the expression of induced resistance also have been found in winter wheat, where increases in yield following ASM treatment were observed only in a susceptible cultivar (66), and in bell peppers expressing resistance induced by ASM treatment (56). In some interesting recent work, Romero and Ritchie (57) examined the effect of ASM in reducing the occurrence of race-change mutants of $X$. axonopodis pv. vesicatoria that overcome major resistance $(\mathrm{R})$ genes in bell pepper. In field experiments, they found that decreased disease severity brought about by ASM treatment was associated with a reduction in the number of race-change mutants and a suppression of disease caused by such mutants. Based on these data, Romero and Ritchie (57) suggest that induced resistance agents may be useful for increasing the durability of genotype-specific resistance conferred by major $\mathrm{R}$ genes.

Genotypic effects on the expression of ISR by PGPR also have been demonstrated. Thus, in Arabidopsis thaliana, the PGPR strain Pseudomonas fluorescens WCS417r elicited ISR on all ecotypes examined, except ecotypes Wassilewskija and RLD $(69,71)$. Subsequent research demonstrated the presence of a locus (ISRI) involved in the ethylene signaling pathway of $A$. thaliana. The ecotypes Wassilewskija and RLD carried a recessive trait that affected ISR by perturbing ethylene signaling, although these plants could still express SAR (68). Clearly, in ecotypes of A. thaliana, allelic variability exists in genes that exert an influence on ISR pathways.

The cost of induced resistance. Following an inducing treatment, there is usually a short lag period before local or systemic resistance is expressed (34). In fact, following the lag period, there are several possible outcomes in terms of resistance expression, the major ones being (i) defenses are triggered and there is no further change in defenses following pathogen challenge, (ii) defenses are triggered and there is a further increase in these defenses or the activation of a different set of defenses following pathogen challenge, and (iii) defense mechanisms are not expressed until pathogen challenge has occurred (72). Whichever of these scenarios prevails following pathogen challenge of an induced plant, there can be a gap of perhaps several days before the plant is protected by its induced defenses. This is a risky form of defense compared with constitutive resistance, where defenses are always present. The continued and indeed widespread existence of induced resistance suggests a selective advantage over constitutive resistance or that induced resistance is more targeted at the invading organism than we sometimes think (i.e., is more specific and less general). For example, the response of plants to the closely related elicitors ASM and SA is different, with different genes being upregulated (22). A possible explanation for this selective advantage lies with fitness costs, where resistant plants would have decreased reproductive success (e.g., seed production) than nonresistant plants under conditions where there was no pathogen pressure (24). These costs can include allocation costs arising from the diversion of metabolites and energy from growth and other processes toward defense; negative effects of the resistance against symbiotic interactions such as formation and functioning of mycorrhizas; and trade-offs where increased resistance to pathogens, for example, might compromise resistance to insect pests (24).

There is evidence that induced resistance to insect herbivores incurs costs (77). However, the situation with respect to pathogens is much less clear. In some pioneering work, SmedegaardPetersen and Stolen (63) found that, when barley was heavily inoculated with an avirulent isolate of powdery mildew, there was a $7 \%$ reduction in grain yield and a $4 \%$ reduction in grain size and grain protein content compared with uninoculated control plants. They suggested that the greatly increased respiration rates observed early in the interaction were required to provide energy for resistance to the attempted powdery mildew infection, and that this was responsible for the reductions in grain yield and quality (63). In contrast, later work reported yield increases associated with induced resistance to powdery mildew infection in barley, compared with plants receiving no inducing treatment $(46,67)$ or no effect on yield when yeast-derived elicitors were used to induce resistance to mildew in barley (51). However, none of these studies was designed to quantify allocation costs, because they all were conducted in the presence of pathogen challenge (24). When two such studies were conducted, using wheat and bean, differing results were obtained. In one study, using ASM applied to wheat in the absence of pathogen pressure, treated plants were shown to have reduced biomass and reduced numbers of ears and grains, with the most pronounced effects detected when nitrogen supply was limited (25). This work demonstrated quite clearly that use of ASM incurred allocation costs, supporting the "growth-differentiation balance" hypothesis, which assumes a metabolic competition between processes involved in plant growth and those necessary for plant differentiation (e.g., the synthesis of chemicals for plant defense) (26). In the second study, Iriti and Faoro (30) found that, in bean treated with ASM, the efficiency of photosystem II was not affected, as was seed quality, although there was a small, statistically insignificant reduction in seed yield. The authors concluded that ASM did not induce fitness costs in bean (30). The different results obtained in these two studies $(25,30)$ probably reflect differences between species and in environmental conditions.

Some of the strobilurin group of fungicides, notably the BASF product F500, which contains pyraclostrobin as the active ingredient, have effects on the plant's metabolism in addition to direct toxin activity against pathogens (27). These include claims of disease resistance induction. Strobilurins also often result in yield benefit beyond that attributable to disease control, partially accounted for by "leaf greening" effects in common with other fungicides such as the triazoles, but this again is genotype and environment dependent (5). Whereas in the absence of fungicide treatments, pathogen-challenged (diseased) and unchallenged genotypes still show high yield correlation, Newton and Thomas (43) found that fungicide-treated pathogen-challenged (no disease) and 
unchallenged genotypes showed no yield correlation. How much more effect on yield-genotype interactions might induced resistance or metabolic change agents have than the conventional fungicides used in this work?

Environmental effects and induced resistance. It stands to reason that, if induced resistance requires the diversion of resources away from growth and development toward defense, constraints on the availability of such resources should exert an impact on the expression of induced resistance. This also could affect the magnitude of any costs associated with induced resistance. Surprisingly, however, this aspect of induced resistance has received little attention until recently. As noted above, Heil et al. (25) found that allocation costs associated with use of ASM on wheat were greatest when nitrogen supply was limited. In later work, nitrogen supply was shown to exert a marked effect on the expression of both constitutive and induced resistance in Arabidopsis (13). In this work, constitutive levels of chitinase, chitosanase, and peroxidase and levels of chitinase and peroxidase in plants induced by ASM treatment were significantly lower under limiting nitrogen supply. Although the maximum activity of chitosanase was not significantly different in induced plants, the induction kinetics of the enzyme were severely affected by nitrogen limitation. Further, total soluble protein content decreased significantly in the first $12 \mathrm{~h}$ following ASM treatment (13), an observation that agrees with a number of studies demonstrating reductions in the expression of genes related to primary metabolism following elicitation of resistance (64). Such a downregulation of primary metabolism may be necessary in order to make available substrates and metabolites required for the de novo synthesis of resistance compounds (23). This concept has received further support recently following work by Dietrich et al. (14), which showed that Arabidopsis plants treated with ASM exhibited a growth reduction during the week following induction. Induced plants appeared to compensate for these growth reductions subsequently by increasing growth rates. These data are interesting in the light of previous work demonstrating increased rates of photosynthesis in upper, uninfected leaves of plants with lower leaves infected by a biotrophic pathogen (55). Murray and Walters (41) showed that upper, uninfected leaves of otherwise rust-infected broad bean plants exhibited not just increased rates of photosynthesis but also enhanced resistance to rust infection. Zeier et al. (79) showed that SAR development in Arabidopsis in response to infection by avirulent bacteria was completely lost when the primary infection process occurred in the absence of light. It would be interesting and useful to determine whether the initial downregulation of primary metabolism observed rapidly following resistance induction is followed thereafter by large increases in primary metabolism (e.g., photosynthesis). In the work of Dietrich et al. (14), the effect of resistance induction on seed production (i.e., whether fitness costs were induced or not) was determined by environmental conditions such as nitrogen supply, water stress, and competition with other plants. They observed costs, no costs, or even higher seed production by ASM-induced compared with uninduced controls, under different combinations of these environmental factors. Induced plants were most likely to incur fitness costs if grown in a competitive environment (14).

It has been known for some time that exposure to abiotic stress can influence plant resistance to pathogens. The interaction between environmental stress and plant disease was reviewed by Ayres in 1984 (2), when he proposed two possible outcomes of such an interaction. The first is the possibility that the negative effects of pathogens and abiotic stress might be additive, and the second possibility is that abiotic stress might alter plant resistance to pathogen infection, leading, for example, to enhanced resistance (2). In fact, water stress has been reported to increase susceptibility to foliar pathogens (45), but also has been shown to enhance resistance to powdery mildew in older leaves of barley grown in dry soil (3). In some interesting work demonstrating the importance of crop growth conditions for the expression of pathogen resistance, Newton and Young (44) and Baker et al. (4) found that relief of water stress leads to a breakdown of mlo resistance in spring barley, and sudden cold relief can have the same effects (K Stewart, S Gurr, and A Newton, unpublished data). More recently, Wiese et al. (76) showed that osmotic stress and proton stress led to the induction of active defenses against powdery mildew in barley. The defense was found to be dependent on the intensity of the stress and the pathogen was stopped by the formation of papillae (76). Interestingly, resistance to mildew was induced in the same concentration-dependent manner by application of abscisic acid to the rooting medium (76). These reports demonstrate the fact that the expression of host resistance can be influenced by abiotic stress, and highlight the need for such interactions to be taken into account when induced resistance is used in a field situation.

\section{OTHER FACTORS THAT MAY INFLUENCE THE EFFECTIVENESS OF INDUCED RESISTANCE}

The ultimate aim of research on induced resistance is its use to control disease in practical, commercial situations. As already indicated, because induced resistance is a host response, it is likely to be affected by the environment and by genotype. But we must not forget that induced resistance will need to fit into cropprotection programs. Therefore, it also will be important to consider the timing of application and frequency of application, and use it in conjunction with appropriate-dose fungicides. These are not trivial issues, because they will affect not only the performance of induced resistance but also its cost effectiveness. Should a resistance elicitor be applied before or after a fungicide application? The answer to this question may depend upon the particular pathogen or pathogens being targeted and the stage of crop growth when they are most prevalent and troublesome. Combinations of agents that induce resistance (e.g., ASM) with fungicides or biological control agents has been shown to provide effective disease control, especially in situations where achieving acceptable disease control is difficult. For example, a mixture of a strobilurin fungicide and ASM was shown to be effective in controlling Albugo occidentalis and increasing leaf quality in spinach (35), while a mixture of ASM and mancozeb was shown to have potential to provide protection against Claviceps africana on sorghum, especially where fungal isolates resistant to the usual fungicide treatment, triadimenol, were present (58). More recently, Gent and Schwartz (15) found that integration of ASM and biological control agents with copper hydroxide could be used to replace less desirable fungicides without compromising effective control of Xanthomonas leaf blight on onion. If agents that induce resistance are to be used in integrated disease control programs, then other questions need to be answered. Will incorporation of induced resistance into disease control programs be more expensive than current approaches? Will induced resistance represent a sustainable approach to disease control? These are all issues that need to be addressed, because it is not good enough to show that a new approach to disease control works under experimental conditions. However, their different mode of action dictates that they cannot and should not be applied in the same way as fungicides and, therefore, they represent a challenge to conventional marketing and agronomic approaches. Ultimately, farmers and growers need to be convinced that induced resistance really will provide a useful, practical, and sustainable approach to dealing with their disease problems.

\section{CONCLUSION}

Plant disease control in the 21st century faces considerable challenges. There are the continuing problems of pathogen adaptability leading to fungicide resistance and breakdown in the effec- 
tiveness of host genetic resistance. Then there are the newer problems of a slowing down in the rate of delivery of new fungicides to the market and the increasing public concern related to the environmental effects of widespread fungicide use. There is also the potential problem of climate change and its impact on pathogen spread. The aim of plant pathologists always has been to keep one step ahead of the pathogens, through understanding every aspect of the plant-pathogen interaction and the factors that influence it. Because of these issues and the fact that plant-pathogen interactions continue to evolve, the need for understanding will not diminish. There clearly is a great deal we understand about induced resistance, but there is equally a great deal still to understand. In our haste to realize the great potential offered by induced resistance for disease control, we have paid too little attention to the factors that are likely to influence its effectiveness in the field, largely using it inappropriately as simply a fungicide replacement. Therefore, in addition to the studies of the molecular regulation of induced resistance, there is an urgent need for information on, and understanding of, the various factors (such as genotype and environment) that will influence the expression of induced resistance under field conditions.

\section{ACKNOWLEDGMENTS}

Scottish Agricultural College and Scottish Crop Research Institute received financial support from the Scottish Executive Environment and Rural Affairs Department.

\section{LITERATURE CITED}

1. Agostini, J. P., Bushong, P. M., and Timmer, L. W. 2003. Greenhouse evaluation of products that induce host resistance for control of scab, melanose and Alternaria brown spot of citrus. Plant Dis. 87:69-74.

2. Ayres, P. G. 1984. The interaction between environmental stress injury and abiotic disease physiology. Annu. Rev. Phytopathol. 22:53-75.

3. Ayres, P. G., and Woolacott, B. 1980. Effects of soil water level on the development of adult plant resistance to powdery mildew in barley. Ann. Appl. Biol. 94:255-263.

4. Baker, S. J., Newton, A. C., Crabb, D., Guy, D. C., Jefferies, R. A., Mackerron, D. K. L., Thomas, W. T. B., and Gurr, S. J. 1998. Temporary partial breakdown of mlo resistance in spring barley by sudden relief of soil water stress under field conditions: The effects of genetic background and mlo allele. Plant Pathol. 47:401-410.

5. Bayles, R. 1999. The interaction of strobilurin fungicides with cereal varieties. Plant Var. Seeds 12:129-140.

6. Benhamou, N., Kloepper, J. W., and Tuzun, S. 1994. Induction of systemic resistance to Fusarium crown rot and root rot in tomato plants by seed treatment with chitosan. Phytopathology 84:1432-1444.

7. Benhamou, N., Kloepper, J. W., and Tuzun, S. 1998. Induction of resistance to Fusarium wilt of tomato by combination of chitosan and endophytic bacterial strain: Ultrastructure and cytochemistry of host response. Planta 204:153-168.

8. Cohen, Y. 1994. 3-Aminobutyric acid induces systemic resistance against Peronospora tabacina. Physiol. Mol. Plant Pathol. 44:273-288.

9. Cohen, Y., Reuveni, M., and Baider, A. 1999. Local and systemic activity of BABA (DL-3-aminobutyric acid) against Plasmopara viticola in grapevines. Eur. J. Plant Pathol. 105:351-361.

10. Cole, D. L. 1999. The efficacy of acibenzolar-S-methyl, an inducer of systemic acquired resistance, against bacterial and fungal diseases of tobacco. Crop Prot. 18:267-273.

11. Conrath, U., Thulke, O., Katz, V., Schwindling, S., and Kohler, A. 2001. Priming as a mechanism in induced systemic resistance of plants. Eur. J. Plant Pathol. 107:113-119.

12. Dann, E., Diers, B., Byrum, J., and Hammerschmidt, R. 1998. Effect of treating soybean with 2,6-dichloroisonicotinic acid (INA) and benzothiadiazole (BTH) on seed yields and the level of disease caused by Sclerotinia sclerotiorum in field and greenhouse studies. Eur. J. Plant Pathol. 104:271-278.

13. Dietrich, R., Ploss, K., and Heil, M. 2004. Constitutive and induced resistance to pathogens in Arabidopsis thaliana depends on nitrogen supply. Plant Cell Environ. 27:896-906.

14. Dietrich, R., Ploss, K., and Heil, M. 2005. Growth responses and fitness costs after induction of pathogen resistance depend on environmental conditions. Plant Cell Environ. 28:211-222.

15. Gent, D. H., and Schwartz, H. F. 2005. Management of Xanthomonas leaf blight of onion with a plant activator, biological control agents, and copper bactericides. Plant Dis. 89:631-639.

16. Gorlach, J., Volrath, S., Knauf-Beiter, F., Hengy, G., Beckhove, U., Kogel, K.-H., Oostendorp, M., Staub, T., Ward, E., Kessmann, H., and Ryals, J. 1996. Benzothiadiazole, a novel class of inducers of systemic acquired resistance, activates gene expression and disease resistance in wheat. Plant Cell 8:629-643.

17. Gottstein, H. D., and Kuc, J. 1989. Induction of systemic resistance to anthracnose in cucumber by phosphates. Phytopathology 79:176-179.

18. Graham, J. H., and Leite, R. P. 2004. Lack of control of citrus canker by induced systemic resistance compounds. Plant Dis. 88:745-750.

19. Hadwiger, L. A. 1999. Host-parasite interactions: Elicitation of defence responses in plants with chitosan. Pages 185-200 in: Chitin and Chitinases. P. Jolles and R. A. A. Muzzarelli, eds. Birkhauser Verlag, Switzerland.

20. Hammerschmidt, R. 1999. Induced disease resistance: How do induced plants stop pathogens? Physiol. Mol. Plant Pathol. 55:77-84.

21. Heath, M. C. 1998. Apoptosis, programmed cell death and the hypersensitive cell death. Eur. J. Plant Pathol. 104:117-124.

22. Heidel, A. J., and Baldwin, I. T. 2004. Microarray analysis of salicylic acid- and jasmonic acid-signalling in responses of Nicotiana attenuata to attack by insects from multiple feeding guilds. Plant Cell Environ. 27:1362-1373.

23. Heil, M. 2002. Ecological costs of induced resistance. Curr. Opin. Plant Biol. 5:1-6.

24. Heil, M., and Baldwin, I. T. 2002. Fitness costs of induced resistance: Emerging experimental support for a slippery concept. Trends Plant Sci. 7:61-67.

25. Heil, M., Hilpert, A., Kaiser, W., and Linsenmair, E. 2000. Reduced growth and seed set following chemical induction of pathogen defence: Does systemic acquired resistance (SAR) incur allocation costs? J. Ecol. 88:645-654.

26. Herms, D. A., and Mattson, W. T. 1992. The dilemma of plants: To grow or to defend. Q. Rev. Biol. 67:238-335.

27. Hermes, S., Seehaus, K., Koehle, H., and Conrath, U. 2002. A strobilurin fungicide enhances the resistance of tobacco against tobacco mosaic virus and Pseudomonas syringae pv. tabaci. Plant Physiol. 130:120-127.

28. Hijwegen, T., and Verhaar, M. A. 1994. Effects of cucumber genotype on the induction of resistance to powdery mildew, Sphaerotheca fuliginea, by 2,6-dichloroisonicotinic acid. Plant Pathol. 44:756-762.

29. Huth, W., and Balke, K. 2002. Bion-without effect on the development of BYDV infected plants of winter barley. J. Plant Dis. Prot. 109:286-290.

30. Iriti, M., and Faoro, F. 2003. Does benzothiadiazole-induced resistance increase fitness cost in bean? J. Plant Pathol. 85S:265-270.

31. Iwata, M. 2001. Probenazole-a plant defence activator. Pest. Outlook Feb 2001:28-31.

32. Jakab, G., Cottier, V., Toquin, V., Rigoli, G., Zimmerli, L., Metraux, J.-P., and Mauch-Mani, B. 2001. $\beta$-Aminobutyric acid-induced resistance in plants. Eur. J. Plant Pathol. 107:29-37.

33. Kessmann, H., Oostendorp, M., Staub, T., Goerlach, J., Friedrich, L., Lawton, K., and Ryals, J. 1996. CGA 245704, mode of action of a new plant activator. Pages 961-966 in: Brighton Crop Protection ConferencePests and Diseases. British Crop Protection Council, Farnham, UK.

34. Kuc, J. 1982. Induced immunity to plant diseases. BioScience 32:854860.

35. Leskovar, D. I., and Kolenda, K. 2002. Strobilurin plus acibenzolar-smethyl controls white rust without inducing leaf chlorosis in spinach. Ann. Appl. Biol. 140:171-175.

36. Mandahar, H. K., Lyngs Jorgensen, H. J., Mathur, S. B., and SmedegaardPetersen, V. 1998. Resistance to rice blast induced by ferric chloride, dipotassium hydrogen phosphate and salicylic acid. Crop Prot. 17:323-329.

37. Martenelli, J. A., Brown, J. K. M., and Wolfe, M. S. 1993. Effects of barley genotype on induced resistance to powdery mildew. Plant Pathol. 42:195-202.

38. Miles, A. K., Willingham, S. L., and Cooke, A. W. 2004. Field evaluation of strobilurins and a plant activator for the control of citrus black spot. Aust. Plant Pathol. 33:371-378.

39. Mitchell, A. F., and Walters, D. R. 2004. Potassium phosphate induces systemic protection in barley to powdery mildew infection. Pest Manage. Sci. 60:126-134.

40. Mucharromah, E., and Kuc, J. 1991. Oxalate and phosphates induce systemic resistance against diseases caused by fungi, bacteria and viruses in cucumber. Crop Prot. 10:265-270.

41. Murray, D. C., and Walters, D. R. 1992. Increased photosynthesis and resistance to rust infection in upper, uninfected leaves of rusted broad bean (Vicia faba L.). New Phytol. 120:235-242.

42. Nakashita, H., Yoshioka, K., Yasuda, M., Nitta, T., Arai, Y., Yoshida, S., and Yamaguchi, I. 2002. Probenazole induces systemic acquired resistance in tobacco through salicylic acid accumulation. Physiol. Mol. Plant Pathol. 61:197-203. 
43. Newton, A. C., and Thomas, W. T. B. 1994. Detection of tolerance of barley cultivars to infection by powdery mildew (Erysiphe graminis $\mathrm{f}$. $\mathrm{sp}$. hordei). Euphytica 75:179-187.

44. Newton, A. C., and Young, I. M. 1996. Temporary partial breakdown of Mlo-resistance in spring barley by the sudden relief of soil water stress. Plant Pathol. 45:973-977.

45. Oerke, E. C., Krone, C., Jacobi, I., and Schonbeck, F. 1992. Relations between stress-induced modifications of the pathogenesis of Erysiphe graminis hordei and the membrane components of barley. J. Phytopathol. 134:157-169.

46. Oerke, E. C., Steiner, U., and Schonbeck, F. 1989. Zur wirksamkeit der induzierten resistenz unter praktischen anbaubedingungen. V. Mehltaubefall und ertag von winter- und sommergerste in abhangigkeit von der stcckstoffdungung. Z. Pflanzenkrankh. Pflanzenschutz 96:140-153.

47. Oostendorp, M., Kunz, W., Dietrich, B., and Staub, T. 2001. Induced disease resistance in plants by chemicals. Eur. J. Plant Pathol. 107:19-28.

48. Orober, M., Siegrist, J., and Buchenauer, H. 2002. Mechanisms of phosphate-induced resistance in cucumber. Eur. J. Plant Pathol. 108:345-353.

49. Perez, L., Rodriguez, M. E., Rodriguez, F., and Roson, C. 2003. Efficacy of acibenzolar-S-methyl, an inducer of systemic acquired resistance, against tobacco blue mold caused by Peronospora hyoscyami f. sp. tabacina. Crop Prot. 22:405-413.

50. Pieterse, C. M. J., Van Wees, S. C. M., Van Pelt, J. A., Knoester, M., Laan, R., Gerrits, H., Weisbeck, P. J., and Van Loon, L. C. 1998. A novel signaling pathway controlling induced systemic resistance in Arabidopsis. Plant Cell 10:1571-1580.

51. Reglinski, T., Newton, A. C., and Lyon, G. D. 1994. Assessment of the ability of yeast-derived elicitors to control powdery mildew in the field. J. Plant Dis. Prot. 101:1-10.

52. Reglinski, T., Newton, A. C., and Lyon, G. D. 1994. Induction of resistance mechanisms in barley by yeast-derived elicitors. Ann. Appl. Biol. 124:509-517.

53. Reuveni, R., Dor, G., Raviv, M., Reuveni, M., and Tuzun, S. 2000. Systemic protection against Sphaerotheca fuligenea in cucumber plants exposed to phosphate in hydroponics system, and its control by foliar spray of mono-potassium phosphate. Crop Prot. 19:355-361.

54. Reuveni, M., Zahavi, T., and Cohen, Y. 2001. Controlling downy mildew (Plasmopara viticola) in field-grown grapevine with $\beta$-aminobutyric acid (BABA). Phytoparasitica 29:2-9.

55. Roberts, A. M., and Walters, D. R. 1986. Stimulation of photosynthesis in uninfected leaves of rust-infected leeks. Ann. Bot. 56:893-896.

56. Romero, A. M., Kousik, C. S., and Ritchie, D. F. 2001. Resistance to bacterial spot in bell peppers induced by acibenzolar-S-methyl. Plant Dis. 85:189-194.

57. Romero, A. A., and Ritchie, D. F. 2004. Systemic acquired resistance delays race shifts to major resistance genes in bell pepper. Phytopathology 94:1376-1382.

58. Ryley, R., Bhuiyan, S., Herde, D., and Gordan, B. 2003. Efficacy, timing and method of application of fungicides for management of sorghum ergot caused by Claviceps africana. Aust. Plant Pathol. 32:329-338.

59. Sharathchandra, R. G., Niranjan Raj, S., Shetty, N. P., Amruthesh, K. N., and Shekar Shetty, H. 2004. A chitosan formulation Elexa induces downy mildew disease resistance and growth promotion in pearl millet. Crop Prot. 23:881-888.

60. Si-Ammour, A., Mauch-Mani, B., and Mauch, F. 2003. Quantification of induced resistance against Phytophthora species expressing GFP as a vital marker: Beta-aminobutyric acid but not BTH protects potato and Arabidopsis from infection. Mol. Plant Pathol. 4:237-248.

61. Siegrist, J., Orober, M., and Buchenauer, H. 2000. $\beta$-aminobutyric acidmediated enhancement of resistance in tobacco to tobacco mosaic virus depends on the accumulation of salicylic acid. Physiol. Mol. Plant Pathol. 56:95-106

62. Silue, D., Pajot, E., and Cohen, Y. 2002. Induction of resistance to downy mildew (Peronospora parasitica) in cauliflower by DL-beta-amino-nbutanoic acid (BABA). Plant Pathol. 51:97-102.

63. Smedegaard-Petersen, V., and Stolen, O. 1981. Effect of energy-requiring defence reactions on yield and grain quality in a powdery mildewresistant cultivar. Phytopathology 71:396-399.

64. Somssich, I. E., and Hahlbrock, K. 1998. Pathogen defence in plants-A paradigm of biological complexity. Trends Plant Sci. 3:86-90.

65. Stadnik, M. J., and Buchenauer, H. 1999. Control of wheat diseases by benzothiadiazole-derivative and modern fungicides. Z. Pflanzenkrankh. Pflanzenschutz 106:466-475.

66. Stadnik, M. J., and Buchenauer, H. 1999. Effects of benzothiadiazole, kinetin and urea on the severity of powdery mildew and yield of winter wheat. Z. Pflanzenkrankh. Pflanzenschutz 106:476-489.

67. Steiner, U., Oerke, E.-C., and Schonbeck, F. 1988. Zur wirksankeit induzierter resistenz unter praktischen anbaubedingungen. IV. Befall und ertrag von wintergerstensorten mit induzierter resistenz und nach fungizidbenandlung. Z. Pflanzenkrankh. Pflanzenschutz 95:506-517.

68. Ton, J., Davison, S., Van Wees, S. C. M., Van Loon, L. C., and Pieterse, C. M. J. 2001. The Arabidopsis ISR1 locus controlling rhizobacteria-mediated induced systemic resistance is involved in ethylene signalling. Plant Physiol. 125:652-661.

69. Ton, J., Pieterse, C. M. J., and Van Loon, L. C. 1999. Identification of a locus in Arabidopsis controlling both the expression of rhizobacteriamediated induced systemic resistance (ISR) and basal resistance against Pseudomonas syringae pv. tomato. Mol. Plant-Microbe Interact. 12:911918.

70. Vallad, G. E., and Goodman, R. M. 2004. Systemic acquired resistance and induced systemic resistance in conventional agriculture. Crop Sci. 44:1920-1934.

71. Van Wees, S. C. M., Pieterse, C. M. J., Trijssenaar, A., Van't Westende, Y. A. M., Hartog, F., and Van Loon, L. C. 1997. Differential induction of systemic resistance in Arabidopsis by biocontrol bacteria. Mol. PlantMicrobe Interact. 6:716-724.

72. Walters, D. R., and Boyle, C. 2005. Induced resistance and allocation costs: What is the impact of pathogen challenge? Physiol. Mol. Plant Pathol. 66:40-44.

73. Walters, D. R., and Murray, D. C. 1992. Induction of systemic resistance to rust in Vicia faba by phosphate and EDTA: Effects of calcium. Plant Pathol. 41:444-448.

74. Walters, D. R., Newton, A. C., and Lyon, G. D. 2005. Induced resistance: Helping plants to help themselves. Biologist 52:28-33.

75. Watanabe, T. 1977. Effect of probenazole (oryzemate) on each stage of rice blast fungus (Pyricularia oryzae Cavara) in its life cycle. J. Pest Sci. 2:395-404.

76. Wiese, J., Kranz, T., and Schubert, S. 2004. Induction of pathogen resistance in barley by abiotic stress. Plant Biol. 6:529-536.

77. Zavala, J. A., Patankar, A. G., Gase, K., Hui, D. Q., and Baldwin, I. T. 2004. Manipulation of endogenous trypsin proteinase inhibitor production in Nicotiana attenuata demonstrates their function as antiherbivore defenses. Plant Physiol. 134:1181-1190.

78. Zehnder, G. W., Murphy, E. J., Sikora, E. J., and Kloepper, J. W. 2001. Application of rhizobacteria for induced resistance. Eur. J. Plant Pathol. 107:39-50

79. Zeier, J., Pink, B., Mueller, M. J., and Berger, S. 2004. Light conditions influence specific defence responses in incompatible plant-pathogen interactions: Uncoupling systemic resistance from salicylic acid and PR-1 accumulation. Planta 219:673-683. 